\title{
Rat Pituitary Gland Neoplasm
}

National Cancer Institute

\section{Source}

National Cancer Institute. Rat Pituitary Gland Neoplasm. NCI Thesaurus. Code C132194.

A benign or malignant neoplasm that affects the pituitary gland of a rat. 